\title{
Growth Response of Brassica rapa on the Different Wavelength of Light
}

\author{
Liwayway H. Acero
}

\begin{abstract}
This study was done to determine what wavelengths of light affects the vegetative growth of Brassica rapa grown in pots in urban area. Quasi-experimental method was used in this study. Brassica rapa seedlings were exposed to different colors of light (white blue green, yellow and red) eight hours in the evening for two weeks of vegetative growth. The leaf size, number and color of leaves were monitored. Data was analyzed using ANOVA-single factorial. Result of the study revealed that plants exposed to white color gave the highest length, width and average number of leaves after fourteen days, followed by plants in treatment 3 (green light), treatment 2 (blue light), treatment 4 (yellow light), the least in treatment 5 (red light). Base on the result of the study white colored fluorescent bulb is recommended as supplementary lighting to Brassica rapa grown in pots in urban areas.
\end{abstract}

Index Terms-Brassica rapa, growth response, wavelength of light

\section{INTRODUCTION}

Vegetable is one of the main ingredients in Asian dishes, thus vegetable production is an old industry in the region. However, due to tremendous increase in human population, shortage in land to be used for vegetable production posed an alarming phenomenon especially in urban places. Some areas are blessed with enough natural sunlight year-round that growers do not need to supplement with artificial light. However, if one wishes to grow vegetable in pots in urban areas, wherein insufficient sunlight is a problem some artificial source of lights could be used. Pechay / Pak Choi (Brassica rapa) belongs to genus of cabbage. It is also known as one of the oldest green vegetables in Asia. Brassica rapa, has been selectively cultivated to produce a plant that has an exceptionally short life cycle (30-45 days). By providing ideal (albeit unnatural) conditions of perfect nutrition and continuous light, one can observe germination, leaf formation, budding, flowering, and seed development in a few weeks rather than a few months [1]. The edible part is its leaves. Its length varies from 10 to $30 \mathrm{~cm}$. [2]. Pechay is often used in stews and soups. It isn't tasty by itself, so it needs some salt and other flavor to be added. Meals with Pechay (Brassica rapa) is often completed with other vegetables and fish or meat. The raw leaves has a nutritional value per 100 grams as follows; Energy $20 \mathrm{kcal} / \mathrm{kg}$; Carbohydrates is $3.2 \mathrm{~g}$. dietary fiber $1.2 \mathrm{~g}$., Fat $.2 \mathrm{~g}$., protein $1.2 \mathrm{~g}$., vitamin C $27 \mathrm{mg}$. and sodium $9 \mathrm{mg}$. [3]. This study determines what wavelength of light affects the vegetative growth of pechay

Manuscript received July 14, 2013, revised September 11, 2013

Liwayway H. Acero is with the Department of Sciences, College of Arts and Sciences, San Beda College, Mendiola, Manila Philippines (e-mail: lilyacero1@yahoo.com). grown in pots in urban area. In detail it explains that when plants are grown in different wavelengths, the size, number and color of the leaves was affected.

\section{MATERIALS AND METHODS}

\section{A. Materials}

This research employed quasi-experimental method using five treatments. Each treatment has 5 potted plants composed of 3 sample plants per pot. Each datum per sample plant where added to 2 data from two sample plants per pot. The average where computed and entered as one data per pot. Plants in all treatments were exposed to sunlight during daytime and to different colored fluorescent lights for eight hours during night time for two weeks. Treatment 1, pechay exposed to white colored fluorescent light; treatment 2, pechay exposed to blue colored fluorescent light, treatment 3 , pechay exposed to green colored fluorescent light, treatment 4, pechay exposed to yellow colored fluorescent light and treatment 5, pechay exposed to red colored fluorescent light. To obtain accurate result, each treatment used 5 pots and 3 samples plants per pot. Three healthy leaves were selected per sample plant to obtain its length and width.

\section{B. Methods}

Brassica rapa seeds were germinated following the recommended practice. A day before pricking out the seedlings for transplanting, the seedbed was moistened thoroughly. Brasicca rapa were planted in pots after 15 days germination. One pot has 3 sample plants. The average initial length of three sample plants per pot were collected and entered as one datum per pot in the Table. Plants were watered 10 "ml." for the first 3 days. Additional $5 \mathrm{ml}$. of water was administered every three days, depending on the response of the plants, but equal amount of water was administered in every plant, using graduated cylinder. To control pests and diseases, the use of contact insecticide available in the market was done. It was sprayed following the prescribed dosage of the manufacturer. During day time plants were exposed to sunlight. When it is already evening improvised partitions made of illustration board was installed. Five pots with 3 samples plants per pot (per treatment) were enclosed using improvised partition walls. Fluorescent light were covered with different coloured cling wraps and were installed 1 foot away from the tallest plant in each treatment. The duration of exposure is eight hours, which means fluorescent lights were switched on at around 10:00 P.M and switch off at around 6:00 AM, the following day.

\section{Data Gathered}

The data gathered were collected from 3 sample plants per 
pot and each treatment represents 5 pots. Each datum per sample plant where added to 2 data from two sample plants per pot. The average where computed and entered as one data per pot. Thus, one data per pot was reflected in the Table. These data include the average initial length and width (in "mm.") of the leaves from the base of the petiole to its apex, final length and width (in mm.) of the leaves, per samples, per pot and per treatment, average leaves formed after fourteen days and the color of the leaves after two weeks of vegetative stage.

\section{RESULTS}

\section{A. Average Initial Length of Brasica rapa Leaves in $\mathrm{mm}$}

Table I shows the average initial length, per treatment Plants in Treatment 1 had a mean length of $14.8 \mathrm{~mm}$. Plants in treatment 2 had a mean length of $14.7 \mathrm{~mm}$, plants in treatment 3 with $14.6 \mathrm{~mm}$, treatment 5 with a mean length of 14.2 and the least plants in treatment 4 with $14 \mathrm{~mm}$ mean length. Analysis of variance was employed to determine degree of significance. These differences were however, statistically insignificant which means all plant samples were treated equal on the start of the study.

TABLE I: AVERAGE INITIAL LENGTH OF BRASSICA RAPA IN MM

\begin{tabular}{|c|c|c|c|c|c|}
\hline & T1 & T2 & T3 & T4 & T5 \\
\hline Pot 1 & 19 & 14 & 15 & 14 & 16 \\
\hline Pot 2 & 13 & 14 & 14 & 13 & 13 \\
\hline Pot 3 & 14 & 14.5 & 12 & 13 & 14 \\
\hline Pot 4 & 16 & 15 & 16 & 17 & 15 \\
\hline Pot 5 & 12 & 16 & 16 & 13 & 13 \\
\hline Total & 74 & 73.5 & 73 & 70 & 71 \\
\hline Mean & 14.8 & 14.7 & 14.6 & 14 & 14.2 \\
\hline
\end{tabular}

\begin{tabular}{|l|c|c|c|c|c|c|}
\multicolumn{7}{|c|}{ ANOVA } \\
\hline S.V & S.S & D.F. & M.S & F & P-Value & F crit \\
\hline $\begin{array}{l}\text { Between } \\
\text { Groups }\end{array}$ & 2.36 & 4 & 0.59 & 8 & 0.95 & 2.87 \\
\hline $\begin{array}{l}\text { Within } \\
\text { Groups }\end{array}$ & 63.6 & 20 & 3.18 & & & \\
\hline Total & 65.96 & 24 & & & & \\
\hline
\end{tabular}

TABLE II: AVERAGE INITIAL WIDTH OF BRASSICA RAPA IN MM

\begin{tabular}{|c|c|c|c|c|c|}
\hline & T1 & T2 & T3 & T4 & T5 \\
\hline Pot1 & 14 & 14 & 14 & 12.5 & 16 \\
\hline Pot 2 & 15 & 14 & 15 & 14 & 13 \\
\hline Pot 3 & 13.5 & 14 & 13.5 & 13 & 15 \\
\hline Pot 4 & 15 & 15 & 16 & 15 & 13 \\
\hline Pot 5 & 14 & 13 & 15 & 16 & 13 \\
\hline Total & 61.5 & 60 & 73.5 & 70.5 & 70 \\
\hline Mean & 12.3 & 12 & 14.7 & 14.1 & 14 \\
\hline
\end{tabular}

\begin{tabular}{|l|c|c|c|c|c|c|}
\multicolumn{1}{c|}{ ANOVA } \\
\hline SV & SS & df & MS & F & P-Value & $\begin{array}{c}\text { F } \\
\text { crit }\end{array}$ \\
\hline $\begin{array}{l}\text { Between } \\
\text { Groups }\end{array}$ & 1.74 & 4 & 0.43 & 0.37 & 0.83 & 2.87 \\
\hline $\begin{array}{l}\text { Within } \\
\text { Groups }\end{array}$ & 23.8 & 20 & 1.19 & & & \\
\hline Total & 25.54 & 24 & & & & \\
\hline
\end{tabular}

\section{B. Average Initial Width of Brasica rapa Leaves in $\mathrm{mm}$}

Table II presents the average initial width of the leaves, per treatment was taken .Plants in Treatment 3 had a mean width of $14.7 \mathrm{~mm}$. Plants in treatment 4 had a mean width of 14.1 $\mathrm{mm}$, plants in treatment 5 with a mean width of 14. Plants in treatment 1 had a mean width of $12.3 \mathrm{~mm}$. The least, plants in treatment 2 with $12 \mathrm{~mm}$ mean width. Analysis of variance was employed to determine degree of significance. These differences were however, statistically insignificant which means all plant samples were treated equal in terms of the width of the leaves, on the start of the study.

TABLE III: AVERAGE FINAL LENGTH OF BRASSICA RAPA IN MM

\begin{tabular}{|c|c|c|c|c|c|}
\hline & T1 & T2 & T3 & T4 & T5 \\
\hline Plant 1 & 47 & 36.5 & 48 & 33 & 35 \\
\hline Plant 2 & 39 & 37 & 42 & 34 & 33 \\
\hline Plant 3 & 42 & 41 & 37 & 37 & 29 \\
\hline Plant 4 & 43 & 40 & 37.5 & 42 & 45 \\
\hline Plant 5 & 41 & 36 & 41 & 43 & 29 \\
\hline Total & 212 & 190.5 & 205.5 & 189 & 171 \\
\hline Mean & 42.4 & 38.1 & 41.1 & 37.8 & 34.2 \\
\hline
\end{tabular}

\begin{tabular}{|l|c|c|c|c|c|c|}
\hline \multicolumn{1}{|c|}{ ANOVA } \\
S.V & S.S & D.F. & M.S & F & P-Value & F crit \\
\hline $\begin{array}{l}\text { Between } \\
\text { Groups }\end{array}$ & 156.3 & 4 & 39.09 & 2 & 0.053 & 2.87 \\
\hline $\begin{array}{l}\text { Within } \\
\text { Groups }\end{array}$ & 277.1 & 20 & 13.85 & & & \\
\hline Total & 433.4 & 24 & & & & \\
\hline
\end{tabular}

\section{Average Final Length of Brassica rapa Leaves in $\mathrm{mm}$}

Table III expresses the average final length, of the leaves per treatment. It was measured after 14 days from transplanting. Brassica rapa were on their vegetative stage. Plants in Treatment 1 had a mean length of $42.4 \mathrm{~mm}$. Plants in treatment $3,41.1 \mathrm{~mm}$, plants in treatment 2 with a mean length of 38.1 Plants in treatment 4 with $37.8 \mathrm{~mm}$ and the least plants in treatment 5 with 34.2 mean length. Analysis of variance was employed to determine degree of significance. These differences were however, statistically insignificant. However if we noticed, plants in treatment 1 (white fluorescent light) gave the highest mean length of the leaves. Fluorescent lighting is used as artificial light in plant growth chambers and extends day length for plants grown in greenhouse conditions. Cool white fluorescent is efficient for most crops. Peas grown in growth rooms, were affected by ethylene which was produced by the ballast chokes present in fluorescent light [4]. Clear light or white light is made up of all of these colors of light, white light is ideal for plant growth. Beans grown under the clear light bulb grew the highest out of the plants compared with the red, blue and yellow light [5]. The wavelength that influences the vegetative growth of the plant is from $400-520 \mathrm{~nm}$. Which is consists of green, violet and blue bands [6].

\section{Average Final width of Brassica rapa Leaves}

Table IV shows the average final width of the leaves. Plants in Treatment 1 had a mean width of $35.4 \mathrm{~mm}$. Plants in treatment 3 had a mean width of $32.1 \mathrm{~mm}$, plants in treatment 2 with a mean width of 31.4. Plants in treatment 4 had 30.8 $\mathrm{mm}$ mean width. The least was in treatment 5, with $27.6 \mathrm{~mm}$ mean width. Analysis of variance was employed to determine degree of significance. These differences were however, statistically insignificant. A study on bean plants can attest to this result. Beans grown under the red light grew significantly smaller in leaf size. Since clear light or white 
light is made up of all of these colors of light, white light is ideal for plant growth. It will always have some color that will be absorbed, regardless of the type of plant [7]. Similar finding was obtained on the study about Light quality on Lettuce plant. It showed that blue light inhibited shoot production while red light either had no effect on lettuce plants [8].

TABLE IV: AVERAGE FINAL WIDTH OF BRASSICA RAPA IN MM

\begin{tabular}{|c|c|c|c|c|c|}
\hline & T1 & T2 & T3 & T4 & T5 \\
\hline Plant 1 & 34 & 32 & 27.5 & 31 & 29 \\
\hline Plant 2 & 36 & 28 & 31 & 29 & 27.5 \\
\hline Plant 3 & 29 & 31 & 35 & 27 & 28 \\
\hline Plant 4 & 43 & 35 & 39 & 35 & 29.5 \\
\hline Plant 5 & 35 & 31 & 28 & 32 & 24 \\
\hline Total & 177 & 157 & 160.5 & 154 & 138 \\
\hline Mean & 35.4 & 31.4 & 32.1 & 30.8 & 27.6 \\
\hline
\end{tabular}

ANOVA

\begin{tabular}{|l|c|c|c|c|c|c|}
\hline S.V & S.S & D.F. & M.S & F & P-Value & F crit \\
\hline $\begin{array}{l}\text { Between } \\
\text { Groups }\end{array}$ & 115.2 & 4 & 28.8 & 1.6 & 0.23 & 3.05 \\
\hline $\begin{array}{l}\text { Within } \\
\text { Groups }\end{array}$ & 270.5 & 15 & 18.03 & & & \\
\hline Total & & & & & & \\
\hline
\end{tabular}

TABLE V: AVERAGE LEAVES FORMED AFTER 14 DAYS

\begin{tabular}{|c|c|}
\hline Treatment Number & Average number of Leaves \\
\hline 1 & 3.6 \\
\hline 2 & 3.4 \\
\hline 3 & 3.5 \\
\hline 4 & 3.3 \\
\hline 5 & 3 \\
\hline
\end{tabular}

E. Average Leaves Formed and Color of the Leaves after 14 Days

Table V, presents the average leaves formed after fourteen days. Treatment 1 (white light) had the highest average leaves produced (3.6), followed by treatment 3 (green light) has 3.5 leaves formed, treatment 2 (blue light) 3.3 leaves, treatment 4 (yellow light) has 3.4 and the least plants in treatment 5 (red light) has an average of 3 leaves formed. Colors that don't have a high wavelength have a high level of energy to grow. Thus, plants in white color had the highest tendency to generate more cells in the foliage of beans [9].

After fourteen days of observation, plants in all treatments exhibit healthy color green, except for plants in treatment 5, wherein some leaves appear distorted crunchy and burned. Bean plants expose to red light became brownish in appearance, after 10 days of bean growth. It had spots on the leaves that felt crunchy and dried up. The stem was thin and the plant appeared to droop, almost as though the stem wasn't strong enough to hold it up Green light is more efficiently transmitted through the plant body and acts as a signal to tissues not directly exposed to the light environment. Therefore, the supplemental green light enhances biomass accumulation in the above-ground part of the plants, and also affects chlorophyll and carotenoid synthesis, thus improving the color of leaves [10].

\section{CONCLUSION}

Base on the result of the study white colored fluorescent light is recommended as supplementary lighting to Brassica rapa grown in pots in urban area. The researcher would like to recommend a follow-up study on increasing the number of hours of plant exposure to different colours of fluorescent light to obtain a significant result An in-depth study should be conducted exposing greenhouse plants to different colours of fluorescent light and determining its effect not only in vegetative stage of the plant but up to flowering phase as well.

\section{ACKNOWLEDGMENT}

The author acknowledges her invaluable mentor Dr. Ricardo Bagarinao, of the University of the Philippines-Open University in Los Banos Laguna, Philippines for the wisdom. For the encouragement of administrators from San Beda College, Manila; Dr. Fedeliz Tuy, Associate Vice- Dean, for Arts, Humanities and Sciences Cluster, College of Arts and Sciences, Dr. Christian Bryan S. Bustamante, ViceDean-CAS and Dr. Tessie R. Da Jose, Dean.

\section{REFERENCES}

[1] BRASSICA - Foss. (2013, August 6). [Online]. Available: http://hsfoss.org/fossweb/teachers/materials/plantanimal/brassica.htm 1

[2] M. Ratikanta, Crop Plant Anatomy, 1st ed. SPI, Pondicherry, India. 2012, Ch. 5, pp. 41

[3] Domain eingeben. (2012, May 5). [Online]. Available: http:// www.bioscience.ws"encyclopedia, index.php?title=Plant_physiology

[4] Effects of Colored Light on Plants. StudyMode.com. (December 2012). [Online]. Available: http://www.studymode.com/essays/Effects-Of-Colored-Light-On-Plan ts.

[5] I. Paul, "Different Colored Lights on the Growth of Bean Plants," Brazilian Journal of Plant Physiology, vol. 17, no. 3, pp. 21-22, July/Sept, 2005.

[6] E. Cao and R. Rivero, Biology a Study Guide, 1st ed., University of the Philippines-Open University, Printing Press, CP Garcia Avenue, Diliman Quezon City Philippines 2005, ch. 3, pp. 21-22A

[7] D. Pooja, Understanding Plant Physiology, 2nd ed., Discovery Publishing House, PVT, LTD, 4831/24, Ansan Road, Darja Ganj, New Delhi India 2010 ch. 5 pp. 37-38.

[8] D. Hunter and D. Burritt, "Light Quality Influences Adventitious Shoot Production from Cotyledon Explants of Lettuce (Lactuca sativa L.)," Vitro Cellular and Developmental Biology-Plant, vol. 40, issue 2, pp. 215-220, March-April, 2004.

[9] H. Popp, The Effect of Different Light Colours on Plant Growth, Botanical Gazette, vol. 82, no. 3, pp. 306-319, November, 1996.

[10] K. M. Folta and S. A. Maruhnich, "Green light: a signal to slow down or stop," Journal of Experimental Botany, vol. 58. pp. 3099-3111, 2007.

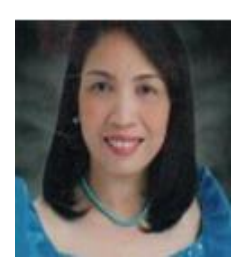

Liwayway H. Acero is a member of Asia Pacific Chemistry, Biology, Environment, Engineering Society, Editorial member for Global Science \& Technology Forum, member of the following national Societies Philippine Society of Animal Sciences, Biology Teachers Association in the Philippines. Research in Education Training Institute (Philippines), National Organization for Professional Teachers (Philippines). International Training Center on Pig Husbandry (Philippines). Place and date of birth: Narra Palawan Philippines on February 18, 1966. Educational background: Doctor of Education major in educational management from Palawan State University on March 2003. Conducted dissertation as research student at Okayama University Graduate School of Education in Japan on March to June 2000. Diploma in science teaching -major in Biology in 2009 from the University of the 
Philippines-open university in Los Banos Laguna. Masters of Science in Agricultural Education major in Agricultural Education minor in Agronomy from the western Philippines university in Aborlan, Palawan, Philippines on April 1993. Bachelor of Science in Agriculture (cum laude), major in animal husbandry and minor in agronomy from the western Philippines university in Aborlan, Palawan, Philippines on April 1986.

She is an assistant professor and the chairperson of the Department of Sciences, College of Arts \& Science in San Beda College, Mendiola, Manila, Philippines. Prior to her employment in San Beda College In Manila, she had served as professor for 20 years in Western Philippines University in Puerto Princesa City, Palawan, Philippines. She handled several administrative works aside from teaching profession. She served as assistant dean of Western Philippines University, Puerto-Princesa Campus from 2004 to 2006 DEPARTMENT CHAIRPERSON of the Education Department from
2003-2006. Department chairperson of the Agribusiness Department \& CHAIRPERSON for the thesis committee from 2000-2003. She had 6 publications. Four of which are international publications. From the latest. Growth Performance of Fatttening Hogs Fed with Fresh and Dried Cashew Apples. CBEES Journal Volume 51 series 2013. Glucose 6-Phosphate Dehydrogenase Enzyme Deficiency Among Infants: An Eye Opener to Parents and Would Be Parents. CBEES Journal Volume 48, series 2012. The Okayama University Graduate School of Education and Palawan State University Graduate School of Education: A Comparative Study: Global Science Technology Forum. November 2011. Article on the Characteristics of Philippine Native Swine. Mason, I. L. A World Dictionary of Livestock Breeds, Types and Varieties. Fourth Edition. 1996. 